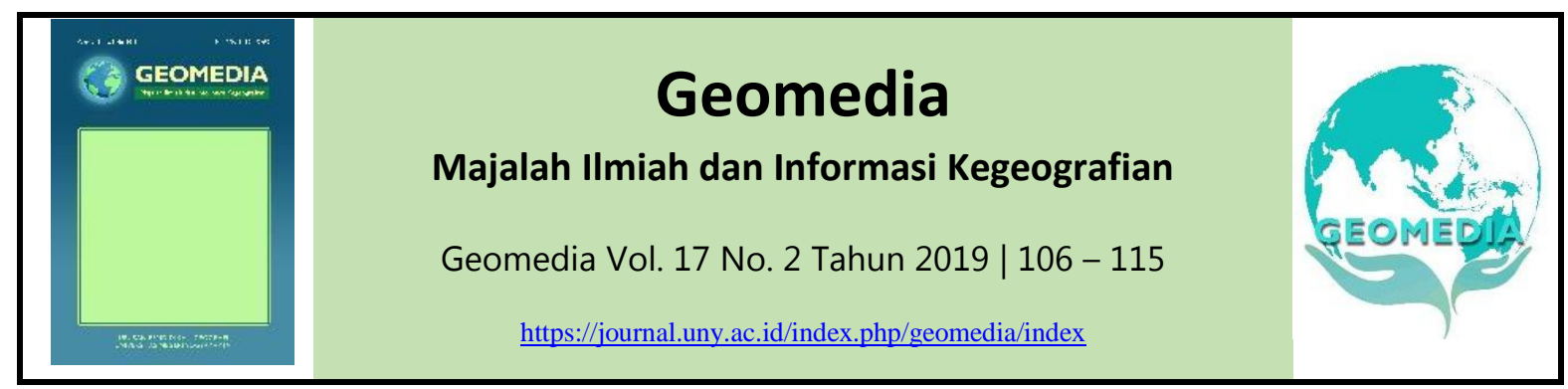

\title{
Lansia Tangguh “7 (Tujuh) Dimensi” di Kota Yogyakarta (Kasus: Lansia di Badran RW XI, Kelurahan Bumijo, Kecamatan Jetis)
}

\section{Sri Agustin Sutrisnowati ${ }^{1^{*}}$, Nurul Khotimah, Mawanti Widyastuti}

Program Studi Pendidikan Geografi Fakultas Ilmu Sosial Universitas Negeri Yogyakarta, Yogyakarta, Indonesia

${ }^{1}$ sri_agustin@uny.ac.id*

*korespondensi penulis

\begin{tabular}{ll}
\hline Informasi artikel \\
\hline Sejarah artikel & \\
Diterima & $:$ \\
Revisi & $:$ \\
Dipublikasikan & $:$ \\
\hline
\end{tabular}

\section{Kata kunci:}

Lansia

Lansia Tangguh

7 (tujuh) dimensi

\begin{abstract}
A B S T R A K
Penelitian ini bertujuan untuk mengetahui : (1) kondisi lansia tangguh "7 (tujuh) dimensi" di Kota Yogyakarta, dan (2) faktor yang paling berhubungan dengan kondisi lansia tangguh "7 (tujuh) dimensi" di Kota Yogyakarta. Penelitian ini merupakan peneltian deskriptif yang dilakukan di Kota Yogyakarta dengan mengambil kasus lansia di Badran RW XI, Kelurahan Bumijo, Kecamatan Jetis, yang telah mendapat intervensi BKL. Variabel penelitian ini adalah kondisi lansia tangguh "7 (tujuh) dimensi" dan faktor-faktor yang berhubungan dengan kondisi lansia tangguh "7 (tujuh) dimensi". Sampel ditentukan secara kuota sampling, yaitu sebanyak 50 orang. Data penelitian dikumpulkan dengan metode observasi, wawancara, dan dokumentasi. Data penelitian selanjutnya dianalisis secara deskriptif berdasarkan data tabel frekuensi dan hasil uji statistik korelasi pearson. Hasil penelitian menunjukkan bahwa: (1) kondisi lansia tangguh 7 (tujuh) dimensi di daerah penelitian didominasi dengan kategori sedang, (2) faktor yang paling berhubungan dengan kondisi lansia tangguh 7 (tujuh) dimensi adalah pendidikan lansia, dengan nilai korelasi pearson sebesar 0.385 atau korelasi cukup.
\end{abstract}

\section{Keywords:}

Elderly

Resilient elderly

7 (seven) dimensions

\begin{abstract}
A B S T R A C T
This study aims to determine: (1) the resilient elderly condition "7 (seven) dimensions" in Yogyakarta City, and (2) the factors most related to the resilient elderly condition "7 (seven) dimensions" in Yogyakarta City. This research is a descriptive study conducted in Yogyakarta City by taking the case of the elderly in Badran RW XI, Bumijo Village, Jetis Sub-district, which has received $B K L$ intervention. The variables of this study are the condition of elderly responsibility "7 (seven) dimensions" and the factors associated with the condition of resilient elderly "7 (seven) dimensions". The sample is determined by sampling quota, which is 50 people. Research data were collected by the method of observation, interviews, and documentation. Subsequent research data were analyzed descriptively based on frequency table data and Pearson correlation statistical test results. The results showed that: (1) the condition of resilient elderly 7 dimensions in the study area dominated by the medium category, (2) the factors most related to the resilient elderly condition of 7 dimensions were elderly education, with a Pearson correlation value of 0.385 or sufficient correlation.
\end{abstract}




\section{Pendahuluan}

Undang-Undang Republik Indonesia No. 13 Tahun 1998 tentang Kesejahteraan Lansia mengemukakan bahwa lanjut usia (lansia) adalah seseorang yang mencapai usia 60 tahun ke atas. Di Kota Yogyakarta, jumlah penduduk lansia tahun 2011 sebesar 9,7\% dari keseluruhan penduduk (BPS, 2012). Kota Yogyakarta termasuk berstruktur penduduk tua karena persentase lansianya lebih dari 7\%. Tingginya jumlah penduduk lansia di Kota Yogyakarta merupakan salah satu indikator keberhasilan pembangunan, namun di sisi lain proses menua pada lansia akan berdampak pada berbagai aspek kehidupan, baik aspek fisiologis, psikologis, maupun sosial ekonomi.

Dampak fisiologis yang dijumpai pada lansia adalah kondisi fisik mulai mengalami penurunan secara perlahan-lahan. Dampak psikologis yang ada pada lansia adalah ditinggal suami/isteri sehingga perlu mencari teman baru untuk berbagi, sedangkan dampak sosial ekomomi adalah adanya gangguan kesehatan dan perubahan status ekonomi dari bekerja menjadi pensiun. Berbagai permasalahan lansia ini harus segera diantisipasi dari sekarang sehingga tidak akan menghambat pembangunan.

Untuk mengantisipasi permasalahan lansia maka yang perlu disiapkan dari sekarang adalah bagaimana mempersiapkan lansia tangguh. Lansia tangguh menurut BBKBN (2014) adalah seseorang atau kelompok lansia yang tetap sehat (secara fisik, sosial, dan mental), mandiri, aktif, dan produktif. Lansia tangguh dapat dilihat dari 7 (tujuh) dimensi, yaitu dimensi spiritual, intelektual, fisik, emosional, sosial kemasyarakatan, profesional vokasional, dan lingkungan. Kondisi lansia tangguh ini tentunya dipengaruhi oleh beberapa faktor, seperti umur, jenis kelamin, dan pendidikan. Berbagai upaya harus dipersiapkan oleh lansia sendiri maupun keluarga ketika usia pra lansia agar nantinya pada usia telah memasuki lansia dapat menjadi tangguh, yaitu tetap sehat, mandiri, aktif, dan produktif, serta tidak menjadi beban keluarga dan masyarakat.

Adanya jumlah lansia yang cukup besar di Kota Yogyakarta tentunya memerlukan perhatian dari berbagai pihak, baik pemerintah, dinas terkait, masyarakat, keluarga, maupun organisasi sosial untuk bersama-sama peduli dan perhatian terhadap lansia. Perhatian terhadap lansia perlu ditingkatkan agar terwujud kualitas keluarga yang sejahtera lahir dan batin karena lansia menghadapi berbagai permasalahan dalam hidupnya, baik fisiologis, psikologis, maupun sosial ekonomi.

Perhatian pemerintah terhadap lansia telah ditunjukkan dengan adanya program Bina Keluarga Lansia (BKL) dari BKKBN, yang bertujuan untuk meningkatkan kesejahteraan lansia (BKKBN, 2011). Adanya intervensi lansia melalui BKL dimungkinkan lansia semakin tangguh dalam menghadapi permasalahan yang dihadapi dan tetap peduli pada masa depan. Berdasarkan hasil penelitian Nurul Khotimah, dkk (2016) diketahui bahwa tingkat peduli masa depan lansia di Kabupaten Bantul, Sleman, dan Gunungkidul berada pada kategori tinggi, sedangkan di Kota Yogyakarta dan Kabupaten Kulonprogro berada pada kategori sedang. Tingkat peduli masa depan lansia di kelima wilayah kabupaten/kota di Daerah Istimewa Yogyakarta yang berbeda dimungkinkan karena peranan kader $\mathrm{BKL}$ di masing-masing wilayah kabupaten/kota tersebut.

Berdasarkan uraian di atas, maka peneliti tertarik untuk melakukan penelitian dengan judul Lansia Tangguh "7 (Tujuh) Dimensi" di Kota Yogyakarta: (Kasus: Lansia di Badran RW XI, Kelurahan Bumijo, Kecamatan Jetis). Tujuan dari penelitian ini adalah mengetahui kondisi dan faktor yang paling berhubungan dengan lansia tangguh "7 (tujuh) dimensi" di Kota Yogyakarta.

\section{Metode}

Metode penelitian yang digunakan adalah penelitian deskriptif yang mengarah pada pengungkapan suatu keadaan sebagaimana adanya dan mengungkap fakta-fakta yang ada 
disertai dengan analisis (Moh. Pabundu Tika, 2005). Penelitian ini difokuskan untuk menggambarkan kondisi lansia "7 (tujuh) dimensi" dan faktor-faktor yang berhubungan dengan kondisi lansia.

Penelitian ini dilaksanakan di Kota Yogyakarta, dengan mengambil kasus di Badran RW XI, Kelurahan Bumijo, Kecamatan Jetis, yang telah mendapatkan intervensi dari BKL Kartini. Adapun waktu pelaksanaan penelitian selama 6 (bulan) sejak bulan Mei hingga Oktober 2015.

Variabel yang digunakan dalam penelitian ini adalah kondisi lansia tangguh "7 (tujuh) dimensi dan faktor-faktor yang berhubungan dengan kondisi lansia tangguh "7 (tujuh) dimensi. Kondisi lansia tangguh "7 (tujuh) dimensi" dilihat dari dimensi sebagai berikut:

1. Dimensi spritual ditandai dengan lansia beriman kepada Tuhan. Agama berperan bagi lansia,

2. Dimensi intelektual ditandai dengan penurunan konsentrasi dan daya ingat, sehingga diperlukan adanya aktivitas untuk mengaktifkan kerja otak,

3. Dimensi fisik ditandai dengan perubahan fisik, penggunaan alat bantu, gangguan penyakit, sehingga diperlukan adanya upaya pemeliharaan kondisi fisik,

4. Dimensi emosional yang ditandai dengan perubahan emosional, sehingga diperlukan adanya upaya menghadapi permasalahan emosional

5. Dimensi sosial kemasyarakatan yang ditandai dengan adanya kepedulian dengan sesama dan partisipasi dalam kegiatan sosial kemasyarakatan,

6. Dimensi profesional vokasional yang ditandai dengan adanya pengembangan usaha ekonomi produktif,

7. Dimensi lingkungan yang ditandai dengan partisipasi kegiatan lingkungan fisik, partisipasi kegiatan lingkungan non fisik.

Selain indikator lansia tangguh "7 (tujuh) dimensi" di atas, variabel yang digunakan lainnya adalah faktor-faktor yang berhubungan dengan kondisi lansia tangguh "7 (tujuh) dimensi" yang meliputi jenis kelamin, umur, dan pendidikan.

Populasi dalam penelitian ini adalah seluruh penduduk lansia yang ada di Badran RW XI, Kelurahan Bumijo, Kecamatan Jetis, Kota Yogyakarta. Jumlah lansia yang menjadi sampel penelitian ditentukan secara quota sampling, yaitu sebanyak 50 orang.

Data yang dikumpulkan dalam penelitian ini meliputi data primer dan data sekunder. Data primer diperoleh dengan teknik pengumpulan data melalui observasi dan wawancara, sedangkan data sekunder diperoleh melalui dokumentasi. Observasi dilakukan dengan mengamati keadaan lansia dan lingkungannya di daerah penelitian. Wawancara dilakukan terstruktur, dengan terlebih dahulu membuat kuisioner yang digunakan untuk memberikan pertanyaan kepada lansia di daerah penelitian. Dokumentasi dilakukan dengan mendatangi instansi terkait seperti BPS, BKKBN, dan lainnya untuk mendapatkan data sekunder sebagai pendukung penelitian, baik melalui buku, catatan, dokumen, dan sebagainya.

Data yang sudah ada selanjutnya dilakukan editing, koding, dan tabulasi. Data yang telah ditabulasi kemudian dianalisis secara deskriptif kuantitatif. Analisis deskriptif adalah berdasarkan gambaran keadaan atau data yang diperoleh dilapangan, sedangkan analisis kuantitatif dengan analisis non statistik (tabel frekuensi) dan analisis statistik (product moment pearson correlation).

Kondisi lansia tangguh "7 (tujuh) dimensi" dibagi menjadi 3 (tiga) tingkat, yaitu tingkat rendah, sedang, dan tinggi. Cara yang digunakan untuk mengklasifikasikan kondisi lansia tangguh "7 (tujuh) dimensi" adalah dengan menentukan interval skor menggunakan rumus sebagai berikut:

interval skor $=\frac{\text { nilai tertinggi }- \text { nilai terendah }}{\text { jumlah } \text { kelas }}$ 
Asumsi nilai skor kondisi lansia tangguh "7 (tujuh) dimensi" ditunjukkan oleh Tabel 1.

Tabel 1. Skor kondisi lansia tangguh "7 (tujuh) dimensi"

\begin{tabular}{|c|c|c|c|}
\hline No & Indikator & $\begin{array}{l}\text { Kondisi Lansia } \\
\text { Tangguh "7 } \\
\text { (tujuh) dimensi" }\end{array}$ & Skor \\
\hline \multirow[t]{2}{*}{1} & \multirow{2}{*}{$\begin{array}{l}\text { Lansia beriman } \\
\text { kepada Tuhan }\end{array}$} & $\mathrm{Ya}$ & 1 \\
\hline & & Tidak & 0 \\
\hline \multirow[t]{2}{*}{2} & \multirow{2}{*}{$\begin{array}{l}\text { Agama berperan } \\
\text { bagi manusia }\end{array}$} & $\mathrm{Ya}$ & 1 \\
\hline & & Tidak & 0 \\
\hline \multirow[t]{2}{*}{3} & \multirow{2}{*}{$\begin{array}{l}\text { Penurunan } \\
\text { konsentrasi }\end{array}$} & $\mathrm{Ya}$ & 0 \\
\hline & & Tidak & 1 \\
\hline \multirow[t]{2}{*}{4} & \multirow{2}{*}{$\begin{array}{l}\text { Penurunan daya } \\
\text { ingat }\end{array}$} & $\mathrm{Ya}$ & 0 \\
\hline & & Tidak & 1 \\
\hline \multirow[t]{2}{*}{5} & \multirow{2}{*}{$\begin{array}{l}\text { Adanya aktivitas } \\
\text { untuk } \\
\text { mengaktifkan } \\
\text { kerja otak }\end{array}$} & $\mathrm{Ya}$ & 1 \\
\hline & & Tidak & 0 \\
\hline \multirow[t]{2}{*}{6} & \multirow[t]{2}{*}{ Perubahan fisik } & $\mathrm{Ya}$ & 0 \\
\hline & & Tidak & 1 \\
\hline \multirow[t]{2}{*}{7} & \multirow{2}{*}{$\begin{array}{l}\text { Penggunaan alat } \\
\text { bantu }\end{array}$} & $\mathrm{Ya}$ & 0 \\
\hline & & Tidak & 1 \\
\hline \multirow[t]{2}{*}{8} & \multirow{2}{*}{$\begin{array}{l}\text { Gangguan } \\
\text { penyakit }\end{array}$} & $\mathrm{Ya}$ & 0 \\
\hline & & Tidak & 1 \\
\hline \multirow[t]{2}{*}{9} & \multirow{2}{*}{$\begin{array}{l}\text { Adanya upaya } \\
\text { memelihara } \\
\text { kondisi fisik }\end{array}$} & $\mathrm{Ya}$ & 1 \\
\hline & & Tidak & 0 \\
\hline \multirow[t]{2}{*}{10} & \multirow{2}{*}{$\begin{array}{l}\text { Perubahan } \\
\text { emosional }\end{array}$} & $\mathrm{Ya}$ & 0 \\
\hline & & Tidak & 1 \\
\hline \multirow[t]{2}{*}{11} & \multirow{2}{*}{$\begin{array}{l}\text { Adanya upaya } \\
\text { menghadapi } \\
\text { permasalahan } \\
\text { emosional }\end{array}$} & $\mathrm{Ya}$ & 1 \\
\hline & & Tidak & 0 \\
\hline \multirow[t]{2}{*}{12} & \multirow{2}{*}{$\begin{array}{l}\text { Adanya } \\
\text { kepedulian } \\
\text { dengan sesama }\end{array}$} & $\mathrm{Ya}$ & 1 \\
\hline & & Tidak & 0 \\
\hline \multirow[t]{2}{*}{13} & \multirow{2}{*}{$\begin{array}{l}\text { Partisipasi dalam } \\
\text { kegiatan sosial } \\
\text { kemasyarakatan }\end{array}$} & $\mathrm{Ya}$ & 1 \\
\hline & & Tidak & 0 \\
\hline \multirow[t]{2}{*}{14} & \multirow{2}{*}{$\begin{array}{l}\text { Adanya } \\
\text { pengembangan } \\
\text { usaha ekonomi } \\
\text { produktif }\end{array}$} & $\mathrm{Ya}$ & 1 \\
\hline & & Tidak & 0 \\
\hline \multirow[t]{2}{*}{15} & \multirow{2}{*}{$\begin{array}{l}\text { Partisipasi } \\
\text { kegiatan } \\
\text { lingkungan fisik }\end{array}$} & $\mathrm{Ya}$ & 1 \\
\hline & & Tidak & 0 \\
\hline 16 & Partisipasi & $\mathrm{Ya}$ & 1 \\
\hline & $\begin{array}{l}\text { kegiatan } \\
\text { lingkungan non } \\
\text { fisik }\end{array}$ & Tidak & 0 \\
\hline Jur & lah & Skor tertinggi & 16 \\
\hline & & Skor terendah & 0 \\
\hline
\end{tabular}

Sumber: Peneliti (2015)

Berdasarkan tabel 1 diketahui skor tertinggi adalah 16 dan skor terendah adalah 0 , sehingga jika jumlah kelas adalah 3, maka interval skor sebagai berikut:

$$
\text { interval skor }=\frac{16-0}{3}=5,3
$$

Interval skor tersebut selanjutnya dapat digunakan untuk menentukan tingkat kategori kondisi lansia tangguh "7 (tujuh) dimensi" ditunjukkan oleh Tabel 2.

Tabel 2. Tingkat kategori kondisi lansia tangguh "7 (tujuh) dimensi"

\begin{tabular}{|c|c|c|}
\hline No & Interval Skor & Kategori \\
\hline 1. & $0-5$ & Rendah \\
\hline 2. & $6-11$ & Sedang \\
\hline 3. & $12-16$ & Tinggi \\
\hline
\end{tabular}

Untuk mengetahui faktor yang paling berhubungan dengan kondisi lansia tangguh "7(tujuh) dimensi ", digunakan analisis statistik Product Moment Pearson Correlation. Interprestasi kekuatan hubungan antara dua variabel sebagai berikut: (1) > 0 - 0,25: korelasi sangat lemah, (2) > 0,25 - 0,5: korelasi cukup, (3) > 0,5 - 0,75: korelasi kuat, (4) > 0,75 - 0,99: korelasi sangat kuat, dan (5) 1: korelasi sempurna.

\section{Hasil dan pembahasan}

\section{Kondisi Lansia Tangguh 7 (Tujuh) Dimensi di Kota Yogyakarta}

Penelitian dilakukan terhadap 50 responden yang terdiri dari 10 laki-laki (20\%) dan 40 perempuan (80\%) lansia. Jumlah perempuan yang lebih banyak menandakan bahwa angka harapan perempuan lebih tinggi dibandingkan dengan laki-laki. Responden diambil dari usia 60 tahun ke atas. Data sebaran usia responden ditunjukkan oleh Gambar 1. 


\section{Sebaran Umur Responden}

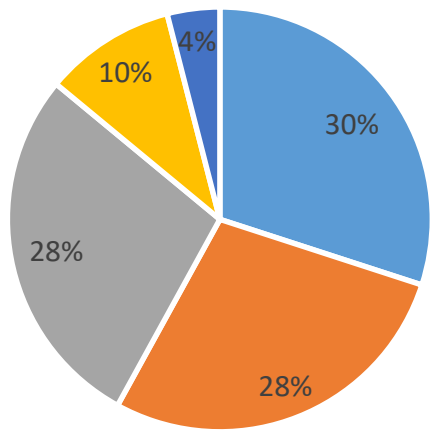

$\square 60-64=65-69 \square 70-74=75-79 \square>79$

Gambar 1. Sebaran Umur Responden

Sumber: analisis lapangan tahun 2015

Berdasarkan Gambar 1, diketahui bahwa jumlah responden terbanyak berkisar antara umur 60 - 64 sejumlah 30\%, kemudian umur 65 69 dan 70 - 74 tahun dengan jumlah 28\%. Banyaknya umur 60 - 64 tahun merupakan lansia yang memungkinkan memiliki kondisi yang tangguh.

Tingkat pendidikan responden bervariasi, mulai dari tidak tamat SD hingga tamat akademi/ perguruan tinggi. Pendidikan penting bagi lansia karena dimungkinkan lansia dapat terus diberdayakan dengan memanfaatkan pengetahuan dan keterampilan sesuai minatnya.

Berikut adalah uraian tujuh dimensi lansia tangguh, dilihat dari dimensi spiritual, intelektual, fisik, emosional, sosial kemasyrakatan, profesional vokasional, dan lingkungan.

\section{Dimensi Spiritual}

Dimensi spiritual merupakan dimensi yang menggambarkan kondisi hubungan lansia dan Tuhan. Terdapat dua indikator dalam dimensi spiritual, yaitu keimanan kepada Tuhan dan peran agama bagi lansia. 100\% lansia menyatakan bahwa mereka beriman kepada Tuhan. Lansia meyakini keberadaan Tuhan dan manusia akan kembali kepadaNya, sehingga dimungkinkan mereka akan berperilaku baik dan lebih toleran dengan agama lain.
Selain itu, 100\% lansia juga menyatakan bahwa mereka merasa agama memiliki peran dalam kehidupan seperti mengurangi ketakutan dan kecemasan, serta melatih diri untuk lebih beriman kepada Tuhan. Berdasarkan dimensi spiritual tersebut, diketahui bahwa seluruh lansia memiliki kondisi spiritual yang baik.

\section{Dimensi Intelektual}

Dimensi intelektual merupakan dimensi yang menggambarkan tentang kemampuan berpikir dari lansia. Terdapat tiga indikator dalam dimensi intelektual, yaitu penurunan konsentrasi, penurunan daya ingat, dan upaya untuk mengaktifkan kerja otak.

Gambar 2 berikut adalah data penurunan konsentrasi lansia.

Penurunan Konsentrasi Lansia (\%)

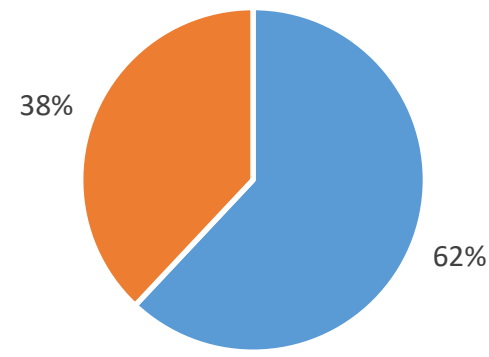

- Tidak mengalami penurunan Konsentras

- Mengalami penurunan konsentrasi

Gambar 2. Penurunan Konsentrasi Lansia sumber: Analisis Lapangan Tahun 2015

Berdasarkan Gambar 2, diketahui bahwa $62 \%$ lansia menyatakan bahwa mereka tidak mengalami penurunan konsentrasi. Hanya 38\% yang menyatakan bahwa mereka mengalami penurunan konsentrasi. Penurunan konsentrasi pada lansia ditandai dengan sulitnya lansia untuk memusatkan perhatian kepada sesuatu.

Gambar 3 menunjukkan penurunan daya ingat pada lansia. 
Penurunan Daya Ingat Lansia (\%)

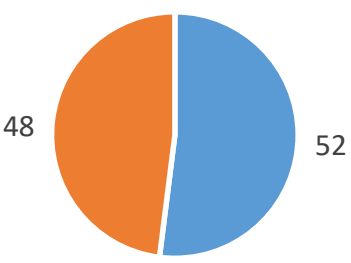

- Tidak mengalami penurunan daya ingat

- Mengalami penurunan daya ingat

Gambar 3. Penurunan Daya Ingat Lansia

Sumber: analisis lapangan tahun 2015

Berdasarkan Gambar 3, diketahui bahwa $48 \%$ menyatakan bahwa mereka mengalami penurunan daya ingat. Sedangkan 52\% menyatakan mereka mengalami daya ingat. Penurunan daya ingat lansia ditandai dengan lupa nama orang, peristiwa, meletakkan sesuatu, dan lain-lain.

Dimensi intelektual juga didukung dengan upaya lansia untuk mengaktifkan kerja otak. Gambar 4 merupakan data upaya lansia yang melakukan aktifitas kerja otak.

Aktivitas untuk Mengaktifkan Kerja Otak

(\%)

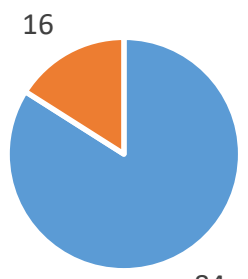

84

- Lansia berusaha melakukan aktivitas untuk mengaktifkan kerja otak

- Lansia tidak berusaha melakukan aktivitas untuk mengaktifkan kerja otak

Gambar 4. Aktivitas untuk Mengaktifkan Kerja Otak

Sumber: Analisis Lapangan Tahun 2015

Berdasarkan Gambar 4 diketahui bahwa 84\% lansia melakukan aktivitas untuk mengaktifkan kerja otak, sedangkan sisanya sebesar 16\% tidak berusaha melakukan aktivitas untuk mengaktifkan kerja otak. Beberapa aktivitas kerja otak yang dilakukan lansia untuk mengaktifkan kerja otak seperti membaca buku, berkebun, menjahit, mengisi teka teki silang, mendongeng ke cucu, bertemu teman, meningkatkan spiritual, dan lain-lain.

\section{Dimensi Fisik}

Dimensi fisik merupakan dimensi yang menggambarkan kondisi fisik dari lansia. Indikator dari dimensi fisik adalah perubahan fisik, penggunaan alat bantu, gangguan penyakit, dan pemeliharaan kondisi fisik. Semua responden menyatakan bahwa mereka mengalami perubahan fisik. Perubahan fisik yang dialami oleh lansia seperti mudah lelah, pendengaran berkurang, penglihatan menurun, rambut memutih, kulit berkeriput, dan gigi mulai tanggal.

Gambar 5 berikut menunjukkan penggunaan alat bantu oleh lansia.

\section{Alat Bantu (\%)}

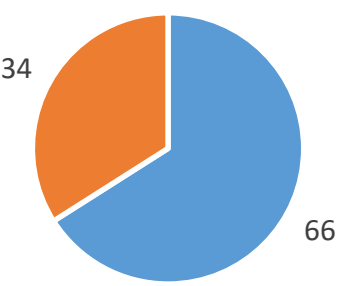

- Tidak memerlukan alat bantu

- Memerlukan alat bantu

Gambar 5. Alat Bantu

Sumber: analisis lapangan tahun 2015

Berdasarkan Gambar 5, diketahui bahwa $66 \%$ lansia menyatakan bahwa mereka tidak memerlukan alat bantu. Hanya 34\% lansia yang menyatakan mereka memerlukan alat bantu. Alat bantu yang banyak digunakan oleh lansia adalah kaca mata.

Berikut Gambar 6 menunjukkan data lansia yang mengalami gangguan penyakit. 


\section{Gangguan Penyakit (\%)}

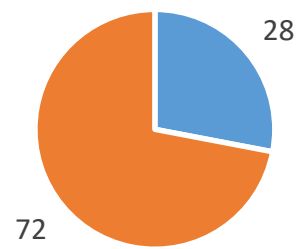

- Tidak mengalami gangguan penyakit

- Mengalami gangguan penyakit

Gambar 6. Gangguan Penyakit

Sumber: analisis lapangan tahun 2015

Berdasarkan Gambar 6, diketahui bahwa $72 \%$ lansia mengalami gangguan penyakit dan hanya $28 \%$ lansia yang tidak mengalami gangguan penyakit. Gangguan penyakit yang banyak dialami oleh lansia adalah hipertensi, kencing manis, jantung, infeksi saluran kemih, anemia, dan sulit tidur.

Upaya yang dilakukan oleh lansia untuk memelihara kondisi fisik seperti rajin mengikuti senam lansia, jalan pagi, makan makanan sehat, cukup tidur, tidak merokok, dan pemeriksaan kesehatan. Seluruh responden menyatakan bahwa mereka telah berusaha memelihara kondisi fisik mereka.

\section{Dimensi Emosional}

Dimensi emosional merupakan dimensi yang mengukur kemampuan lansia untuk mengatur dan mengelola emosinya. Terdapat dua indikator dalam dimensi emosional, yaitu perubahan emosional dan upaya yang dilakukan lansia menghadapi permasalahan emosional.

Berikut Gambar 7 menunjukkan perubahan emosional dari lansia.

\section{Perubahan Emosional (\%)}

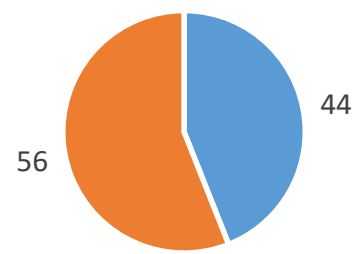

- Tidak mengalami perubahan emosional

- Mengalami perubahan emosional

Gambar 7. Perubahan Emosional

Sumber: analisis lapangan tahun 2015

Berdasarkan Gambar 7, diketahui bahwa perubahan emosional pada lansia terjadi sekitar 56\%. 44\% lainnya menyatakan bahwa mereka tidak mengalami perubahan emosional. Perubahan emosional yang banyak terjadi adalah perubahan dalam merasakan lapar dan haus, panas dan dingin, pahit dan asin, rasa curiga, serta mudah marah dan tersinggung.

Untuk mengatasi perubahan emosional, sejumlah lansia melakukan upaya untuk menghadapi permasalahan tersebut. Berikut Gambar 8 merupakan data upaya yang dilakukan lansia untuk menghadapi permasalahan emosional.

\section{Upaya Menghadapi Permasalahan} Emosional (\%)

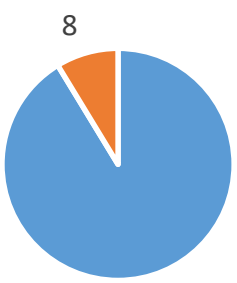

84

- Melakukan upaya menghadapi permasalahan emosional

- Tidak melakukan upaya menghadapi permasalahan emosional

Gambar 8. Upaya Menghadapi Permasalahan Emosional

Sumber: analisis lapangan tahun 2015 
Berdasarkan Gambar 8, diketahui bahwa 84\% lansia menyatakan telah melakukan upaya untuk menghadapi permasalahan emosional dan hanya $16 \%$ yang tidak melakukan upaya tersebut. Contoh upaya yang dilakukan lansia untuk menghadapi permasalahan emosional tersebut adalah sering melakukan silaturahmi, beribadah secara rutin, dan berkegiatan sesuai dengan kemampuan.

\section{Dimensi Sosial Kemasyarakatan}

Dimensi sosial kemasyarakat merupakan kondisi lansia dalam berkehidupan bermasyarakat. Terdapat dua indikator dalam dimensi sosial kemasyarakatan, yaitu kepedulian dengan sesama dan partisipasi dalam kegiatan sosial masyarakat.

Seluruh responden lansia menyakatan bahwa mereka telah melakukan upaya membangun kepedulian dengan sesama. Upaya dilakukan diwujudkan dalam bentuk menjenguk saudara, teman, dan atau tetangga yang sakit, melayat, dan melakukan silaturahmi.

Berikut Gambar 9 menunjukkan data partisipasi lansia dalam kegiatan sosial kemasyarakatan.

Partispasi dalam Kegiatan Sosial Kemasyarakatan (\%)

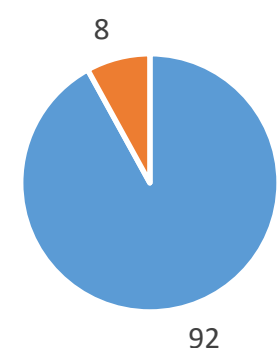

- Berpartisipasi - Tidak berpartisipasi

Gambar 9. Partisipasi dalam Kegiatan Sosial Kemasyarakatan

Sumber: analisis lapangan tahun 2015

Berdasarkan Gambar 9, diketahui bahwa sebanyak 92\% lansia menyatakan bahwa mereka ikut berpartisipasi dalam kegiatan sosial kemasyarakatan. Hanya $8 \%$ lansia yang menyatakan bahwa mereka tidak berpartisipasi dalam kegiatan tersebut. Contoh kegiatan sosial masyarakat yang banyak diikuti lansia adalah kegiatan keagamaan, gotong royong, bakti sosial, kewirausahaan, kesenian, olahraga, dan pendamping kegiatan sosial kemasyarakatan lainnya.

\section{Dimensi Profesional Vokasional}

Dimensi profesional vokasional merupakan kondisi kemampuan lansia dalam mengembangkan dirinya. Indikator dari dimensi profesional vokasional adalah pengembangan usaha ekonomi oleh lansia. Berikut Gambar 10 menunjukkan data lansia yang melakukan usaha ekonomi produktif.

\section{Pengembangan Usaha Ekonomi Produktif}

(\%)

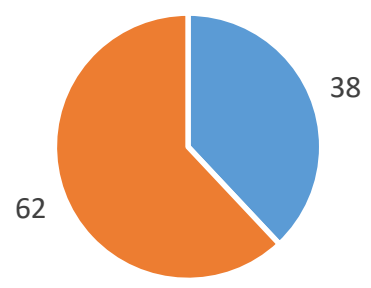

- Melakukan pengembangan usaha ekonomi produktif

- Tidak melakukan pengembangan usaha ekonomi produktif

Gambar 10. Pengembangan usaha ekonomi produktif

Sumber: analisis lapangan tahun 2015

Berdasarkan Gambar 10, diketahui bahwa sebanyak 62\% lansia tidak melakukan usaha ekonomi produktif, sedangkan 38\% sisanya melakukan usaha tersebut. Usaha ekonomi produktif yang dilakukan oleh lansia seperti membatik, bidang kesehatan dan pengobatan tradisional seperti jamu, bidang kuliner, dan bidang industri rumah tangga.

\section{Dimensi Lingkungan}

Dimensi lingkungan merupakan kondisi lansia dalam berpartisipasi di lingkungan 
sekitarnya. Indikator dari dimensi lingkungan adalah partisipasi lansia dalam kegiatan lingkungan fisik dan non fisik.

Berikut Gambar 11 menunjukkan partisipasi kegiatan lingkungan fisik.

Partisipasi Kegiatan Lingkungan Fisik (\%)

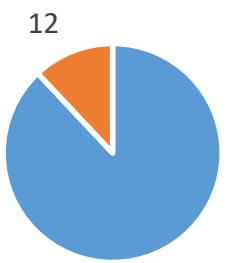

88

- Berpartispasi - Tidak berpatisipasi

Gambar 11. Partisipasi kegiatan lingkungan fisik

Sumber: analisis lapangan tahun 2015

Berdasarkan Gambar 11, diketahui bahwa 88\% lansia menyatakan bahwa mereka berpartisipasi dalam kegiatan lingkungan fisik dan hanya $12 \%$ yang menyatakan bahwa mereka tidak berpartisipasi dalam kegiatan tersebut. Contoh kegiatan partisipasi yang dilakukan di lingkungan fisik adalah mengepel lantai, menyirami tanaman, menyediakan tong sampah, membersihkan ventilasi rumah, dan membersihkan selokan.

Berikut Gambar 12 menunjukkan partisipasi lansia dalam kegiatan lingkungan non fisik.

Partisipasi Kegiatan Lingkungan Non Fisik (\%)

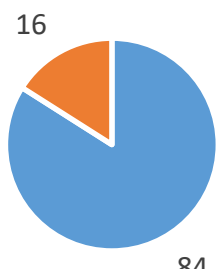

- Berpartisipasi - Tidak berpartisipasi

Gambar 12. Partisipasi lansia dalam kegiatan lingkungan non fisik

Sumber: analisis lapangan tahun 2015

Berdasarkan Gambar 12, diketahui bahwa sebanyak $84 \%$ lansia menyatakan bahwa mereka berpartisipasi dalam kegiatan lingkungan non fisik dan hanya $16 \%$ yang menyatakan bahwa mereka tidak berpartisipasi dalam kegiatan tersebut. Kegiatan lingkungan non fisik yang dilakukan oleh lansia seperti ikut serta dalam kegiatan mental spiritual dan kegiatan sosial budaya.

Dari perhitungan jumlah skor lansia di daerah penelitian berdasarkan 7 dimensi, diketahui skor terendah adalah 6 dan skor tertinggi adalah 15 . Berdasarkan skor terendah dan tertinggi tersebut, maka dibuat 3 kelas kondisi lansia tangguh dengan klasifikasi tingkat rendah yaitu interval skor 6 -9, tingkat sedang yaitu interval $10-12$, dan tingkat tinggi yaitu interbal 13 - 15. Adapun hasil perhitungan ditunjukkan Tabel 3 berikut.

Tabel 3. Kondisi Lansia Tangguh 7 Dimensi

\begin{tabular}{llll}
\hline No & $\begin{array}{l}\text { Kondisi } \\
\text { tangguh 7 dimensi }\end{array}$ & $\begin{array}{l}\text { lansia } \\
\text { Jumlah }\end{array}$ & $\begin{array}{l}\text { Persentase } \\
\text { (\%) }\end{array}$ \\
\hline 1 & Tingkat rendah & 10 & 20 \\
\hline 2 & Tingkat sedang & 22 & 44 \\
\hline 3 & Tingkat tinggi & 18 & 36 \\
\hline & Jumlah & 50 & 100 \\
\hline
\end{tabular}

Sumber: analisis lapangan tahun 2015

Berdasarkan Tabel 3, diketahui bahwa kondisi lansia tangguh di daerah penelitian paling banyak dalam kondisi sedang, yaitu sebanyak $44 \%$, kemudian dengan kondisi lansia tingkat tinggi yaitu sebanyak 36\% dan diikuti dengan tingkat rendah yaitu sebanyak $20 \%$.

\section{Faktor yang Paling Berhubungan dengan Kondisi Lansia Tangguh 7 (Tujuh) Dimensi di Kota Yogyakarta}

Faktor seperti jenis kelamin. umur, dan pendidikan perlu diketahui yang paling berhubungan dengan kondisi lansia tangguh. Berikut Tabel 4 menunjukkan hubungan antara jenis kelamin, umur, dan pendidikan dengan kondisi lansia tangguh 7 dimensi. 
Tabel 4. Hubungan antara jenis kelamin, umur, dan pendidikan dengan kondisi lansia tangguh 7 dimensi

\begin{tabular}{ccccc}
\hline & & $\begin{array}{c}\text { Jenis } \\
\text { kelamin }\end{array}$ & Umur & Pendidikan \\
\hline $\begin{array}{c}\text { Lansia } \\
\text { tangguh } \\
\mathbf{7} \text { dimesi }\end{array}$ & $\begin{array}{c}\text { Pearson } \\
\text { Correlation }\end{array}$ & 0.109 & -0.108 & $0.385^{\star \star}$ \\
\hline
\end{tabular}

sumber: analisis lapangan tahun 2015

Berdasarkan Tabel 4, diketahui bahwa faktor yang paling berhubungan dengan kondisi lansia tangguh 7 dimensi adalah pendidikan. Hal ini ditunjukkan oleh nilai Pearson Correlation antara pendidikan dan kondisi lansia tangguh 7 dimensi yaitu sebesar 0.385 (korelasi cukup), jika dibandingkan dengan faktor jenis kelamin dengan nilai 0.109 dan faktor umur dengan nilai 0.108, dan keduanya termasuk korelasi yang sangat lemah. Pendidikan lansia cukup berhubungan dengan kondisi lansia tangguh 7 dimensi karena semakin tinggi pendidikan lansia maka dimungkinkan semakin besar kemampuan lansia dalam pengembangan dimensi spritual, intelektual, fisik, emosional, sosial kemasyarakatan, profesional vokasional, maupun lingkungan.

\section{Simpulan}

Kondisi lansia tangguh "7 (tujuh) dimensi" sebanyak 44\% berada pada tingkat sedang, diikuti $36 \%$ berada pada tingkat tinggi dan sisanya $20 \%$ berada pada tingkat rendah. Faktor yang paling berhubungan dengan kondisi lansia tangguh "7 (tujuh) dimensi" adalah pendidikan lansia, dengan nilai korelasi Pearson sebesar 0,385 (korelasi cukup). Pendidikan lansia cukup berhubungan dengan kondisi lansia tangguh "7 (tujuh) dimensi" karena semakin tinggi pendidikan lansia maka dimungkinkan semakin besar kemampuan lansia dalam pengembangan dimensi spritual, intelektual, fisik, emosional, sosial kemasyarakatan, profesional vokasional, maupun lingkungan.

\section{Ucapan terima kasih}

Penulis mengucapkan terimakasih kepada Fakultas Ilmu Sosial yang telah membiayai penelitian ini melalui Dana DIPA Tahun Anggaran 2015.

\section{Referensi}

BKKBN. (2011) Bina Keluarga Lansia (BKL). Yogyakarta: BKKBN Provinsi Daerah Istimewa Yogyakarta.

BKKBN. (2014). Lansia Tangguh Tujuh Dimensi. Jakarta: BKKBN.

BPS. (2012). Daerah Istimewa Yogyakarta dalam Angka. Yogyakarta: BPS.

Tika., Moh. Pabundu. (2005). Metode Penelitian Geografi . Jakarta: Bumi Aksara.

Khotimah, Nurul., Gunardo., Ghufron, Anik., Sugiharti, Sri., Aryekti, Kanthi. (2016). Lanjut Usia (Lansia) Peduli Masa Depan di Daerah Istimewa Yogyakarta. Geomedia. Vol. 14(2): 51-66.

Undang-Undang Republik Indonesia No. 13 Tahun 1998 tentang Kesejahteraan Lansia. 